\title{
PROCESS OF TRAINING AND INSERTION IN THE LABOR MARKET: A VISION OF NURSING GRADUATES
}

Bruna Pedroso CANEVER , Diana Coelho GOMES ${ }^{b}$, Bruna Helena de JESUS Lia Bortolotto SPILLERE ${ }^{d}$, Marta Lenise do PRADO ${ }^{e}$, Vania Marli Schubert BACKES ${ }^{f}$

\section{ABSTRACT}

Study to analyze nursing graduates' perception about the contribution of the training process in its insertion in the labour market. Descriptive exploratory study, a qualitative approach. The data was collected in 2011 through semistructured interviews. Attended by 15 professionals, graduated from the Nursing Course at a South Brazilian university in 2009-2010, inserted in the labour market. Data was analysed according to Minayo's proposals. From this analysis emerged the category Training route, including the subcategory: following the travel itineray. The results demonstrate the need for curricular integration, better use of clinical practices experiences, research valorization, and the importance of training based on dialogue between students and professors.

Descriptors: Nursing education. Higher education.Curriculum. Labor market.

\section{RESUMO}

Estudo com objetivo de analisar a percepção dos egressos, de um curso de graduação em enfermagem, sobre a contribuição do processo de formação de enfermeiros para sua inserção no mercado de trabalho. Estudo descritivo exploratório, de abordagem qualitativa. Os dados foram coletados em 2011, com entrevistas semiestruturadas. Participaram 15 egressos de uma universidade pública do sul do Brasil, graduados em 2009 e 2010, inseridos no mercado de trabalho. A análise dos dados foi realizada conforme Minayo, emergindo a categoria 'itinerário de formação', com a subcategoria 'seguindo o roteiro de viagem'. Os resultados evidenciam a necessidade da integração curricular, melhor aproveitamento das experiências de práticas clínicas, valorização da pesquisa, importância da formação pautada no diálogo entre discentes e docentes.

Descritores: Educação em Enfermagem. Educação superior. Currículo. Mercado de trabalho.

Título: Processo de formação e inserção no mercado de trabalho: uma visão dos egressos de enfermagem.

\section{RESUMEN}

Estudio que objetivó analizar la percepción de los egresados graduados en la enfermería, sobre la contribución del proceso de formación e inserción al mercado de trabajo. Estudio exploratorio descriptivo, un enfoque cualitativo. Datos fueron colectados en 2011, mediante entrevistas semiestructuradas en los años 2009 y 2010 en el mercado de trabajo. El análisis de datos fue realizado según la propuesta operativa de Minayo. Del análisis emerge la categoría itinerario de formación con subcategoría: Siguiendo la ruta del viaje. Los resultados evidencian la necesidad de una integración curricular, mejor provecho de experiencias en las prácticas clínicas, valorización de la investigación y la importancia de la formación basada en el diálogo entre alumnos y docentes.

Descriptores: Educación en Enfermería. Educación superior. Curriculum. Mercado de trabajo.

Título: Proceso de formación e inserción en el mercado de trabajo: una visión de los egresados de enfermería.

\footnotetext{
a Master in nursing, doctoral student in nursing at Universidade Federal de Santa Catarina (UFSC), Florianópolis, Santa Catarina, Brazil. b Nurse, masters student in nursing at UFSC, Florianópolis, Santa Catarina, Brazil.

c Nurse, masters student in nursing at UFSC, Florianópolis, Santa Catarina, Brazil.

d Nurse, masters student in nursing at Universidade do Extremo Sul de Santa Catarina (UNESC), Florianópolis, Santa Catarina, Brazil.

e PhD in nursing, professor of undergraduate and graduate courses in nursing at UFSC, CNPq researcher, Florianópolis, Santa Catarina, Brazil.

f PhD in nursing, professor of undergraduate and graduate courses in nursing UFSC, CNPq researcher, Florianópolis, Santa Catarina, Brazil.
} 


\section{INTRODUCTION}

The difference between graduate education and labor market demands have made it difficult for graduates to adapt to their professional careers. (1). Therefore, it is necessary to have a better understanding of the status of nursing graduates in order to perform and complement the assessment of the learning process, aimed at understanding the training potential of the institution, the demands of society, the end product of pedagogical work and the insertion of these professionals in the labor market. Besides, a better knowledge on the nursing graduates will help gathering valuable information for the assessment of the Instituto Nacional de Pesquisas Educacionais (INEP) of the Brazilian Ministry of Education and Culture (MEC), which reinforces the need for investigation of graduates ${ }^{(2-4)}$.

In addition to the abovementioned, it is worth stressing that, although other studies were conducted on these professionals ${ }^{(2-4)}$, they were not sufficient to characterize the profile of these nursing graduates from Brazilian institutions, because of the different socio-demographic realities of the country. Yet, these studies are relevant and provide valuable insight on the importance of proper nursing training for insertion in the labor market.

Therefore, the present study was aimed to analyze the perception of nursing graduates on the contribution of nursing training to their insertion in the labor market.

\section{METHODOLOGY}

The present study is an approach of the Term Paper $^{(5)}$ in the Graduate course in Nursing approved by Universidade Federal de Santa Catarina (UFSC), titled "Contribution of critical-creative training in the insertion in the labor market: a vision of nursing graduates". This is a descriptive exploratory study using a qualitative approach, and the methodology used in the qualitative approach was proposed by Minayo. The survey was conducted with graduates in nursing from a public university in southern Brazil, who graduated in 2009- 2010 and are inserted in the labor market. The referred university has 114 graduates in Nursing who graduated in the years 2009 and 2010 and 71 in 2010. The participants were invited by e-mail and social networks, and their addresses were informed by the university. The exclusion criterion was not being inserted in the labor market.

The data was collected in August and September 2011 through semistructured interviews conducted by the researchers at a place and date established by the respondent. The instrument used in data collection was structured in two steps. In the first step, the graduates provided personal data (name and age), year and semester of graduation, current workplace, professional field, previous experiences, and informed whether they were taking postgraduate courses, for the characterization of the profiles of the respondents. In the second step, semistructured interviews especially designed for the study were conducted, and validated by the researchers, which addressed issues related to the process of education/training and insertion in the market labor, beginning of the professional career, expectations met, suggestions regarding the training process to improve professional insertion, significant aspects of training and plans for the professional career. After the development of the instrument, the interviews were carried out without prior pilot test, which did not interfere with data collection.

The interviews were recorded on digital file, transcribed into text file in computer by the researchers and stored in a personal computer with restricted access. The interviews had a minimum duration of 13 minutes and maximum duration of 4.2 minutes, with sampling defined through data saturation. ${ }^{(6)}$

Data analysis was performed according to the following steps: data ordering, were the transcripts of the interviews were done, with re-reading of the material and organization of the reports, classification of data and final analysis, with exhaustive and repeated reading of the texts, apprehension of the relevant structures of the central ideas, formation of thematic categories, cross-reading of the material and relationship with the theoretical reference $^{(7)}$.

The research was approved by the Ethics Committee for Research with Humans of UFSC, registered under number $1942 / 11$, according to Resolution 196/96 of the National Health Council ${ }^{(8)}$.

Participants signed the informed consent form (TCLE) to express their acceptance of the conditions of the research. Confidentiality was ensured 
to all participants who were identified by letter I (interviewee) followed by a numerical order from 1 to 15 .

\section{RESULTS AND DISCUSSION}

Fifteen nursing graduates aged 22-31 years old, 14 women and only one man participated in the study. At the time of data collection, they were performing their activities in different nursing fields, namely: hospital care, family health strategy, telemedicine services, home care, management of public health services, pre-hospital care service, beauty care and teaching (graduate and technical course). Only four participants reported having previous experience in other fields.

Two broad categories emerged from the sorting and classification of the data obtained from the interviews: Training route and Route of insertion in the labor market.

The category Training route addressed information from subjects about their academic career, and this category gave rise to two subcategories: "Following the travel itinerary" and "Expanding horizons: the possibilities in the route”. This article will focus on the results related to the first thematic category: Training route, subcategory "Following the travel itinerary".

\section{Following the travel itinerary}

The subcategory called "following the travel itinerary” concerns curricular activities predetermined as compulsory and that were developed by the graduate during the graduation course. This subcategory addressed themes related to the curriculum, teaching methodologies and was divided into three themes, as follows:

\section{Navigating in the curricular ocean}

The content and workload of curricular subjects during graduation were reported by the graduates as significant experiences that contributed markedly to professional practice, as expressed by the following quote:

Concerning the methodology [care systematization], I use the whole methodology here [workplace] [...] In the fourth stage I learned the methodology; so I use the history, I use the whole nursing care systematization,
I monitor patient progress, prescribe medication, as I learned [...] I think the fifth stage is wonderful, it is the best structured stage [...] the internships well scheduled, we successfully complete all internships in the basic and hospital units $[\ldots](E 6)$.

Generalist training makes it possible for graduates to live different experiences, in the different scenarios of nursing. Thus, it provides a broad overview of the work process, as well as the theoretical and practical bases for the insertion of graduates in the professional market.

On the other hand, some graduates reported deficiencies regarding the schedule and organization of disciplines. They reported feelings related to experiences in clinical practice, the lack of understanding between the teaching staff, the little time for each experience, as well as the difficulties encountered in some disciplines:

Ifound the nursing process discipline, which is taught
in medical practice and surgical practice, very disorga-
nized. There was a teaching staff for each one of the
practices, and when we were doing the internship we
had the impression that the two staffs did not interact
with one another. [...] this was unacceptable, because
they taught the same discipline, they had to communicate
with each other $[\ldots]$... E13)

When pointing out the difficulties and possible issues identified in the nursing course, the graduates showed critical judgment regarding their training, demonstrating, thus, ability to think critically about the reality experienced and its impact on the training of professionals with the potential to change reality. However, it is not enough to think critically about reality: education is the lever for social change, being necessary to engage in the struggle for changes ${ }^{(9)}$.

Regarding the theoretical-practical activities (clinical practice, supervised internships), they were considered the most significant curricular activities by many nursing graduates, and they emphasized their contribution in preparing future professionals for insertion in the market place, as seen in the following quote:

There should have been more time available for this activity [clinical practice], but I felt well prepared as a nursing professional the moment I entered r the labor market]. Entering the labor market and meeting the demands, this was a surprise for me, I didn't expect it.(E5) 
The theoretical-practical activities developed in different settings by students, during their academic period, are significant moments of the learning process: the theoretical knowledge acquired by the student being later put into practice. The short stay in each clinical practice setting is emphasized by the graduates. However, the generalist training is aimed to the establishment of theoretical-practical foundations that assist the insertion of the nursing professional in the several nursing fields. Thus, the broader knowledge of the different specialties should be obtained according to the aptitude and/or field of activity, in a process of continuous education throughout the professional life $\mathrm{e}^{(10)}$.

Still regarding the theoretical-practical relationship, the graduates saw it as positive for their training, reporting that it helped them in knowledge construction, as seen in the quote below:

The training process has provided a great contribution for my insertion in the labor market, particularly regarding the conditions for tests and all activities carried out in the university We examined the diagnosed pathology in detail and then focused on the nursing care, trying to understand how this was applicable to our family, our community., and not merely the patient. (E3)

The graduates perceive that nursing training comprises the theoretical content, which will reflect in their professional activity, so that they will have the ability to think critically and provide better care ${ }^{(10)}$.

The relationship between theory and practice becomes an inseparable link in academic training, because theory and practice should occur simultaneously. This vision attempts to overcome the still existing tendency that separates theory from practice. The theoretical knowledge learned during graduation allows students to establish strategies in their daily professional activities ${ }^{(11)}$.

Some graduates highlighted the importance of a training focused on the SUS (Unified Health System), which facilitates their activities in basic healthcare, as seen in the quote below:

What I felt that should be improved, has improved with this five-year curricular activities. The part related to basic health care had an extensive workload[...]. which I think is very positive, the theoretical content on SUS is broad [...], and well taught in the University.(E3)
The training of health professionals focused on the SUS consists in a governmental policy aimed to strengthen the healthcare system in Brazil. Therefore, the university curriculum should include the principles and guidelines of the SUS, so that nursing graduates are able to participate in solutions for health care issues, aiming to providing a broad and high-quality health care to the population..$^{(12)}$.

However, the graduates are not very aware of the professional profile of their graduation course. This can be seen in the following quote of a graduate that expresses his/her wish to receive a specialist training that fulfills his/her expectations, without the need to undertake postgraduate studies:

Avoid the need to attend further postgraduate courses and other specializations, and acquire all knowledge at graduation.(E2)

This report demonstrates that nursing graduates have a technicist view based on the biomedical model and focused on specialties, corroborating the proposal of the National Guidelines for the graduate nursing course, which recommend that nursing graduates have a generalist, humanist and critical education and develop general competences and skills for health care, decision making, leadership, communication, management and continuing education. ${ }^{(13)}$.

\section{Experiencing different navigation modes: the teaching methodologies in the training process}

The graduates were very concerned about the teaching methodologies experienced by students during graduation. Many believe that the active learning and teaching methodology had a positive role on their learning during the course, as follows:

When I entered university I was very shy and did not
feel comfortable making presentations to the others. But
since we were encouraged to prepare the seminars and
presentations, I finally lost the fear to speak in public
and to acquire these skills. Now I teach them to my
own students.(E2)

The active teaching and learning approaches are emphasized as key tools in the development of competencies and autonomy by the graduates. In the current context of education, these 
methodologies are responsible for providing the growth and development of subjects in the teaching-learning process. However, in order to rethink education, the subject is supposed to think critically and continuously seek knowledge and updating. ${ }^{(14)}$.

On the other hand, some graduates reported having difficulty learning the active methodology applied in the course and said they wanted more lecture classes, as shown below:

Many times I thought I should have attended more lecture classes, with professors teaching the subjects. I did not expect to spend a great deal of time presenting seminar on pathologies. I think nothing replaces a good class. (E7)

The preference for the traditional learning methodology is still strongly evident in the reports of some graduates. The difficulty in taking an independent and libertarian attitude can be associated to the historical context and previous educational experiences, which were characterized by a traditional education where teachers are the holders of the knowledge and the center of the learning process. ${ }^{(15)}$.

Also, some graduates stressed the active teaching methodology role of stimulating the search for knowledge, as shown in the following quote:

The active learning methodology teaches us to study, which is essential in our professional activities, and many people are unaware of it. They think that as soon as they graduate they will have a job.[...] we have to get used to the idea that knowledge should be sought, It is not readily available; I believe the active methodology is much more effective, for I find it easier to remember what I have studied rather than what I have been taught in the classes. (E6)

The graduates admit that the active learning methodology implemented in the course played a key role in their professional training. The awakening of curiosity, the search for answers and questioning stimulate the critical capacity, facilitating the learning process ${ }^{(16-17)}$.

\section{Professors: they supervise the travels}

Regarding the teaching staff, the graduates stressed the affective relationship, which facilitated student learning, as follows:
Some professors are very human in the purest sense of the word. They help you during the internships [...] they are facilitators.(E2)

Thus, professor who facilitate learning are essential during graduation, for they help students develop respect, dedication and taste for their future profession,

On the other hand, some negative aspects regarding substitute professors were reported by some graduates: lack of teaching, pedagogical skills and health care experience, as shown below:

Some professors have no teaching skills, are not prepared to teach in graduate courses [...] there were many substitute teachers, some of them were not prepared and had little professional experience. So they found it difficult to transmit their knowledge and sometimes they even lacked the necessary practice.(E4)

According to the graduate, the unpreparedness of some professors is quite evident, with significant impact on professional training. Teaching requires extensive and diverse knowledge, as well as the continuous search for new knowledge, and this process is an important tool for the nurse educator to establish the relationships between the theoretical and practical bases of the profession ${ }^{(18)}$.

In contrast, the performance of substitute teachers was considered positive by some graduates, who reported that these professors had greater health care practice, compared to the others who had more extensive theoretical knowledge, as follows:

Many people criticize substitute teachers, [...] but they have greater health care practice than the regular professors [...] who cannot teach health care practice. So I prefer a substitute teacher with two years of health care practice than a PhD who has never worked in health care practice. These doctors should not teach us practical lessons. I expect them to teach us theory and stimulate us to think critically [...]. (E6)

The technicist approach is emphasized by the graduates, who value the practical knowledge and technical skills of their professors. The historical context of the nursing profession shows a great emphasis on the mastery of technical skills and even today this is an essential requirement to be met by nurses in the labor market. The mastery of technical procedures is still synonymous of profes- 
sional excellence, to the detriment of theoretical reasoning and scientific knowledge ${ }^{(19)}$.

\section{FINAL CONSIDERATIONS}

The results demonstrate that a training involving critical reflexivity has contributed positively to the insertion of nursing graduates in the labor market and was of utmost importance to the awakening of creativity for solving everyday problems. However, the perception of the graduates involves more conventional and more progressive attitudes regarding their training. Other issues raised by the subjects were the key role of active learning methodologies that promote the autonomy of students, provides training on the SUS and emphasize the need for continuing professional development for teachers.

Among the difficulties of the training process for insertion in the labor market, the main aspect mentioned by the graduates was the discrepancy between the reality of a university hospital (the main practice field during graduation) and the reality of other institutions, both public and private which would possibly come to be the workplace for these graduates. This occurs because unlike other institutions the university hospital has wellequipped facilities to meet the requirements of a high-quality education.

The data obtained in this study provides the teaching staff with supportive elements to think about the training of nursing graduates. By pointing out at the weaknesses and strengths of nursing training, the teaching staff and the students are able to reflect on their professional practice and seek solutions for the weaknesses of the curriculum and training process, and also to maximize the positive aspects.

In short, we highlight the importance of knowing the real impact of graduate courses in nursing on the insertion of nurse graduates in the labor market, as well as the weaknesses and strengths of this training to the beginning of the professional career. Through the perception and experience of newly trained nurses it is possible to qualitatively assess the efficiency of graduate courses in providing a training that stimulates critical thinking, since knowledge changes fast, and the nurses must continuously update their professional expertise also in virtue of ethical imperative of their professional practice.
In view of the above, and since this study concerned only one teaching institution, we understand the need to broaden the scope of the present study to include other teaching institutions, public or private, in order to know the particularities of the training process in nursing in the different Brazilian regions and contribute to improve the pedagogical practices involved in this process, as well as the professional development of nurses.

\section{REFERENCES}

1 Rodrigues RM, Zanetti ML. Teoria e prática assistencial na enfermagem: o ensino e o mercado de trabalho. Rev Latino-Am Enferm. 2000;8(6):102-9.

2 Souza NVDO, Correia LM, Rodrigues BMRD, Pereira AM, Pena DA, Nunes KSM. O enfermeiro e a teoria crítica da educação: sua inserção no mundo do trabalho. Rev Enferm UERJ. 2006;14(4):506-11.

3 Souza NVLDO, Correia LM, Cunha LS, Eccard J, Patrício RA, Antunes TCS. O egresso de enfermagem da FENF/UERJ no mundo do trabalho. RevEsc Enferm USP. 2011;45(1):250-7.

4. Püschel VAA, Inácio MP, Pucci PPA. Inserção dos egressos da Escola de Enfermagem daa USP no mercado de trabalho: facilidades e dificuldades. RevEsc Enferm USP. 2009; 43(3): 535-42.

5 Jesus BH, Gomes DC,Spillere LBB.Contribuição da formação crítico- criativa na inserção no mercado de trabalho: visão de egressos de enfermagem [monografia]. Florianópolis (SC): Universidade do Sul de Santa Catarina, 2011.

6 Fontanella BJB, Ricas J, Turato ER. Amostragem por saturação em pesquisas qualitativas em saúde: contribuições teóricas. Cad Saúde Pública [Internet]. 2008 [citado $2013 \mathrm{dez} 4$ ];24(1):17-27. Disponível em: http://www.scielo.br/pdf/csp/ v24n 1/o2.pdf.

7 Minayo MCS. O desafio do conhecimento: pesquisa qualitativa em saúde. 8. ed. São Paulo: HUCITEC; 2010 .

8 Conselho Nacional de Saúde. Resolução no 196/96 de 10 de outubro de 1996, Institui Diretrizes e Normas Regulamentadoras de Pesquisas envolvendo Seres Humanos. [Internet]. 1996 [citado $2013 \mathrm{dez}$ 5]. Disponível em: http://conselho.saude.gov.br/ resolucoes/1996/Reso196.doc 
9 Freire P. A pedagogia da esperança: um reencontro com a pedagogia do oprimido. Rio de Janeiro: Paz e Terra; 2009.

10 Silva CC, Silva ATMC, Oliveira AKS. Processo avaliativo em estágios supervisionados: uma contribuição para o estudo. Cogitare Enferm. 2007;12(4):42838.

11 Zarpellon LD. A relação teoria e prática no processo de formação do enfermeiro. In: Congresso Nacional de Educação - EDUCERE 7: Anais do VII Congresso Nacional de Educação- EDUCERE [Internet]; 2007 nov 5-8; Curitiba. PUCPR: Champagnat; 2007 [citado 2009 nov 17]. Disponível em: http://www. pucpr.br/eventos/educere/educere2007/anaisEvento/arquivos/CI-193-04.pdf

12 Costa KSC, Miranda FAN. Opinião do graduando de enfermagem sobre a formação do enfermeiro para o SUS: uma análise da FAEN/UERN. Esc Anna Nery Rev Enferm. 2010;14(1):39-57.

13 Conselho Nacional de Educação (BR), Câmara de Educação Superior. Resolução CNE/CES n. 3, de 07 de novembro de 2001:institui Diretrizes Curriculares Nacionais do Curso de Graduação em Enfermagem. [citado 2013 dez 5]. Disponível em:http://portal. mec.gov.br/cne/arquivos/pdf/CESo3.pdf

14 Freire P. Pedagogia da autonomia: saberes necessários à prática educativa. 37.ed. São Paulo: Paz e Terra; 2011.

15 Canever BP. Produção do conhecimento dos grupos de pesquisa em Educação em Enfermagem do estado de São Paulo [dissertação]. Florianópolis (SC): Universidade Federal de Santa Catarina; 2011.

16 Semim GM, Souza MCBM, Corrêa AK. Professor como facilitador do processo ensino-aprendizagem: visão de estudante de enfermagem. Rev Gaúcha Enferm. 2009;30(3):484-91.

17 Paranhos VD, Mendes MMR. Currículo por competências e metodologia ativa: percepção de estudantes de enfermagem. Rev Latino-Am Enferm. 2010;18(1):109-15.

18 Barbosa ECV, Viana LO. Um olhar sobre a formação do enfermeiro/docente no Brasil. Rev Enferm UERJ. 2008;16(3):339-44.

19 Mulato SC. Enfermagem tradicional, atual e do futuro: a visão de docentes de enfermagem. Rev Enferm UERJ. 2010;18(4):572-77.

\section{Author's address / Endereço do autor / Dirección del autor}

Bruna Pedroso Canever

Rua Jornalista Tito de Carvalho, 101, bl. B2.1, ap.102, Trindade 88040480, Florianópolis, SC

E-mail: brunacanever@gmail.com
Received: 28.10.2013

Approved: 20.01.2014 